\title{
Pemikiran Nasaruddin Umar dan Henri Shalahuddin tentang Hadis Kesaksian Wanita: Sebuah Kajian Komparatif
}

\author{
Nurul Azizah \\ Jurusan Ilmu Hadis \\ Fakultas Ushuluddin UIN Sunan Gunung Djati Bandung, Indonesia \\ nuruluinsgd@gmail.com
}

\begin{abstract}
The purpose of this study was to determine the differences in the interpretations of Nasaruddin Umar and Henri Salahuddin in understanding the hadith of women's testimonies. This study uses a qualitative type through literature study using the syarah hadith method and a comparative analysis approach. The results of the research and discussion show that the interpretations of women's testimonies are quite diverse, especially among Islamic feminists and traditional ulama. This study concludes that Nasaruddin Umar follows the feminist interpretation, and understands the hadith of women's testimonies contextually. Nasaruddin argues that reason is something that is universal, men and women have the same capacity in witnessing. Meanwhile, Henri Salahuddin in his normative interpretation follows classical scholars and understands the hadith of women's testimony tends to be textual. According to him, a woman has limitations in reason and religion so that the testimony of two women is equal to one man. This study recommends further research on the hadith of women's testimony with a social science approach.
\end{abstract}

Keywords: Comparative, Women's testimony, Syarah.

Abstrak
Tujuan penelitian ini untuk mengetahui perbedaan
penafsiran Nasaruddin Umar dan Henri Shalahuddin dalam
memahami hadis kesaksian wanita. Penelitian ini
menggunakan jenis kualitatif melalui studi pustaka dengan
menggunakan metode syarah hadis dan pendekatan analisis
komparatif. Hasil penelitian dan pembahasan menunjukkan
bahwa penafsiran-penafsiran terhadap hadis kesaksian
wanita cukup beragam khususnya di kalangan feminis Islam
dan ulama tradisional. Penelitian ini menyimpulkan bahwa
Nasaruddin Umar mengikuti penafsiran feminis, serta


memahami hadis kesaksian wanita secara kontekstual. Nasaruddin berpendapat bahwa akal merupakan sesuatu yang bersifat universal, laki-laki dan wanita memiliki kapasitas yang sama dalam persaksian. Sedangkan Henri Shalahuddin dalam penafsirannya secara normatif mengikuti ulama-ulama klasik dan memahami hadis kesaksian wanita cenderung tekstual. Menurutnya seorang wanita memiliki keterbatasan pada akal dan agama sehingga menyebabkan kesaksian dua wanita sama dengan satu laki-laki. Penelitian ini merekomendasikan untuk meneliti lebih lanjut mengenai hadis kesaksian wanita dengan pendekatan ilmu-ilmu sosial.

Kata kunci: Kesaksian wanita, Komparatif, Syarah.

\section{Pendahuluan}

Terdapat beberapa hadis yang berkaitan dengan kedudukan wanita yang dipahami secara misoginis oleh kaum feminis (Setiawan, 2019). Salah satu hadis tersebut adalah hadis riwayat Imam Bukhari yang menyatakan bahwa penghuni neraka terbanyak adalah kaum wanita serta kelemahannya dari segi akal dan agama. Menurut para feminis, hadis tersebut sangat merendahkan derajat kaum wanita dengan adanya indikasi lain yaitu kesaksian wanita 1 : 2 dari kesaksian laki-laki (Fuadhaili, 2005). Dalam memahami hadis tersebut, terdapat pula perbedaan pemahaman di kalangan pemikir Islam kontemporer di Indonesia. Misalnya, Nasaruddin Umar berasumsi bahwa aturan kesaksian wanita dan laki-laki 1 : 2 dengan dalih perlu direinterpretasi (Umar, 2001). Hal ini berbanding terbalik dengan penjelasan Henri Shalahuddin dengan mengutip pendapat Muhammad Biltaji, menurutnya aturan kesaksian wanita dan laki-laki $1: 2$ merupakan dalil yang bersifat qath'i (pasti) (Shalahuddin, 2016). Terdapat multi pemahaman dalam satu teks, meskipun yang dijadikan objek itu sama. Hal ini menarik untuk dikaji secara lebih mendalam untuk mengungkap keterpengaruhan horizon kedua pemikir tersebut dengan gagasan yang diluncurkan.

Beberapa ahli telah melakukan penelitian seputar hadis kesaksian wanita, seperti dalam tinjuan pustaka ini. Antara lain, Muhammad Rizka (2014) dengan judul "Kritik Nalar Hadis Misoginis." Pendekatan yang dipakai Hermeneutika Kritis. Penelitian ini membahas tentang kritik terhadap nalar pada hadis-hadis Shahih Bukhari yang dianggap misoginis, salah satu bahasannya yaitu hadis tentang kesaksian wanita. Penelitian ini menyimpulkan bahwa dalam memahami hadis tersebut perlu memperhatikan konteks kekinian serta disematkan dengan ilmu-ilmu yang berkembang saat ini. Hadis kesaksian wanita $1: 2$ dari kesaksian laki-laki 
ini bersifat temporal dan situasional (Muqtada, 2014). Selanjutnya terdapat penelitian Setiawan (2019) dengan judul "Perempuan sebagai Mayoritas Penghuni Neraka dan Kelemahannya dari Sisi Akal dan Agama: Sanggahan atas Gugatan Kaum Feminis terhadap Hadis 'Misoginis'." Pendekatan yang dipakai takhrij hadis dan syarah hadis, penelitian ini menyimpulkan bahwa pendapat feminis yang mengutarakan bahwa hadis tersebut mendiskriminasikan kaum wanita tidaklah terbukti apabila dalam memahami hadis tersebut secara komprehensif dan tidak disertai dengan wacana westernisasi (Setiawan, 2019). Ada pula Nazhirah, Z. F. (2018) dengan judul "Penyelesaian Hadis Kontradiksi tentang Kesaksian Perempuan." Penelitian ini menerapkan metode takhrij hadis, teori mukhlatif hadis serta pemahaman kontekstual. Hasil dan pembahasan penelitian ini mengungkap bahwa Nabi Saw. menerima kesaksian wanita bedasarkan kemampuan dan keakurasiannya. Penelitian ini menyimpulkan bahwa diterimanya kesaksian wanita tanpa harus ditemani saksi lain dengan syarat wanita tersebut menguasai dengan baik kesaksiannya (Fauziyyah, 2018). Penulis belum melihat adanya studi komparatif di kalangan tokoh pemikir kontemporer di Indonesia yang membahas seputar hadis tersebut.

Berbagai penelitian terdahulu berharga bagi penyusunan kerangka berfikir penelitian ini. Kesaksian merupakan sebuah keterangan atau pernyataan yang diutarakan oleh seorang saksi (Fauziyyah, 2018). Untuk menjadi seorang saksi perlu memenuhi persyaratan tertentu, hal ini dikarenakan saksi merupakan hal yang sangat penting dalam menjaga dan menegakkan keadilan (Fauziyyah, 2018). Hadis Nabi Saw yang membicarakan tentang kesaksian wanita 1 : 2 dari kesaksian laki-laki tersebar dalam kitab-kitab hadis yang dikeluarkan oleh Bukhari, Muslim, Abu Dawud, Tirmidzi, Ibnu Majah dan Darimi (Setiawan, 2019). Keontetikan hadis ini tidak perlu diragukan, karena telah diriwayatkan oleh imam-imam besar yang termasuk ke dalam Kutub al-Tis'ah (Setiawan, 2019). Ibnu Hajar al-Asqalani dalam kitabnya Fathul Bari menegaskan bahwa hadis kesaksian wanita 1 : 2 dari kesaksian laki-laki bukan merupakan bentuk penghinaan terhadap kaum wanita (Setiawan, 2019). Kesaksian wanita merupakan salah satu tema yang sampai saat ini cukup aktual (Nasaruddin Umar, 2001). Dan terdapat keberagaman dalam memahami hadis kesaksian wanita tersebut, hal ini disebabkan oleh sudut pandang dan basis epistimologi yang mereka gunakan dalam memandang sebuah teks, serta perbedaan kondisi sosio-kultural yang melingkup masing-masing penafsir (Khariroh, 2010).

Bedasarkan rumusan masalah di atas, pertanyaan dalam penelitian ini meliputi bagaimana pandangan umum kesaksian wanita, bagaimana hadis tentang kesaksian wanita dan bagaimana pemahaman pemikiran Nasaruddin Umar dan Henri Shalahuddin tentang hadis kesaksian wanita. 
Penelitian ini bertujuan mengetahui pemahaman serta perbedaan penafsiran Nasaruddin Umar dan Henri Shalahuddin tentang hadis kesaksian wanita. Penelitian ini diharapkan dapat bermanfaat dan menambah ilmu dan wawasan pada semua lapisan masyarakat tentang bagaimana pemahaman Islam feminis dan Islam tradisionalis tentang hadis kesaksian wanita.

\section{Metode Penelitian}

Penelitian ini berjenis kualitatif dengan menerapkan studi pustaka yaitu menghimpun sumber-sumber kepustakaan yang berbentuk primer maupun sekunder (Darmalaksana, Cara Menulis Proposal Penelitian, 2020). Terhadap penelitian hadis digunakan metode syarah hadis, hal ini digunakan untuk mengetahui uraian serta penjelasan ulama terkait hadis yang sedang diteliti (Muhdator, 2016). Dengan pendekatan analisis komparatif yaitu membandingkan pandangan dua atau lebih tokoh pemikir atau penafsir (Zubair, 2010). Dalam mendeskripsikan pemikiran tokoh menggunakan teori fusion of horizons, bedasarkan teori ini bahwa penafsiran seseorang itu terbentuk dari masa lalu atau latar belakang yang melingkup dirinya. Dengan kata lain bahwa teori ini digunakan untuk melihat dimensi historis penafsir baik itu dilihat dari aspek intern, intelektual, politik, sosio-kultural masyarakat yang dihadapi ketika itu (Darmaji, 2013).

\section{Hasil dan Pembahasan}

Hasil penelitian dan pembahasan di bawah ini.

\section{Kesaksian Wanita}

Kesaksian adalah keterangangan atau pernyataan yang disampaikan oleh seorang saksi, yaitu orang yang telah menyaksikan suatu peristiwa atau diharuskan memberikan keterangan atau bukti di depan hakim (Helim I. E., 2015). Asumsi atau prasangka-prasangka yang diperoleh melalui refleksi tidak termasuk dalam kesaksian (Helim I. E., 2015). Dalam hukum Islam alat bukti saksi, yaitu saksi laki-laki disebut dengan syahid, sedangkan saksi wanita dikenal dengan syahidah. Keduanya diambil dari kata musyahadah yang artinya menyaksikan dengan mata kepala sendiri. Dengan kata lain, saksi yang dimaksudkan tersebut merupakan manusia hidup (Fauziyyah, 2018). Dalam kesaksian perlu memenuhi beberapa unsur, seperti adanya sebuah kasus atau peristiwa hukum yang menjadi objeknya, di dalam kasus tersebut terdapat hak-hak seseorang yang perlu ditegakkan dan adanya saksi atau orang yang menyaksikan serta memahami dengan benar peristiwa tersebut, pengetahuan tersebut diserahkan kepada pihak yang berwenang (Fauziyyah, 2018).

Kesaksian termasuk hal yang sangat penting dalam kehidupan, karena berkaitan dengan manusia maupun dengan Tuhan. Oleh karena itu, 
dalam menyampaikan sebuah kesaksian disyariatkan untuk memenuhi beberapa kriteria, yaitu baligh, berakal sehat, tidak bisu atau dapat berbicara, muslim, baik, adil serta dapat mengingat dengan baik sebuah peristiwa (Fauzan, 2005). Nashr Farid Washil, menambahkan tidak ada unsur paksaan dalam menyampaikan kesaksian. Sedangkan Sayyid Sabiq menambahkan pula bahwa seorang saksi itu harus memiliki ingatan yang baik serta terbebas dari segala tuduhan negatif (tidak ada permusuhan) (Anshoruddin, 2004).

Hukum kesaksian dalam Islam adalah fardu kifayah, termasuk kesaksian yang dilakukan oleh wanita. Kesaksian wanita dapat diterima di semua perkara yang tidak mungkin disaksikan oleh laki-laki. Diterimanya kesaksian wanita dikuatkan dengan prinsip-prinsip syariat dalam kondisi tertentu (Shalahuddin, 2016). Mengenai kedudukan wanita menjadi saksi dalam undang-undang Islam digolongkan menjadi tiga bagian yaitu: a) Kesaksian wanita yang tidak dapat diterima, seperti dalam masalah jarimah hudud, jarimah qisas (menurut Imam Syafi'i dengan madzhabnya); b) Kesaksian wanita dapat diterima secara mutlak, hal ini menyangkut persoalan hak-hak badan yang hanya boleh dilihat oleh wanita; dan c) Kesaksian wanita dapat diterima tidak secara mutlak, harus didampingi oleh laki-laki, misalnya dalam hal perkawinan, rujuk dan wasiat dan keuangan (menurut Abu Hanifah dengan madzhabnya) (Fauziyyah, 2018). Kedudukan saksi dalam Islam memperhatikan pada kualitas dan integritas moral, terlepas apapun gendernya (Shalahuddin, 2016).

\section{Hadis Kesaksian Wanita}

\section{a) Teks Hadis Kesaksian Wanita}

Terdapat sejumlah matan hadis berkaitan dengan kesaksian wanita separuh dari kesaksian laki-laki (Fauziyyah, 2018). Di antaranya, matan (teks) hadis tersebut dalam kitab Shahih al-Bukhari Nomor 293 sebagai berikut:

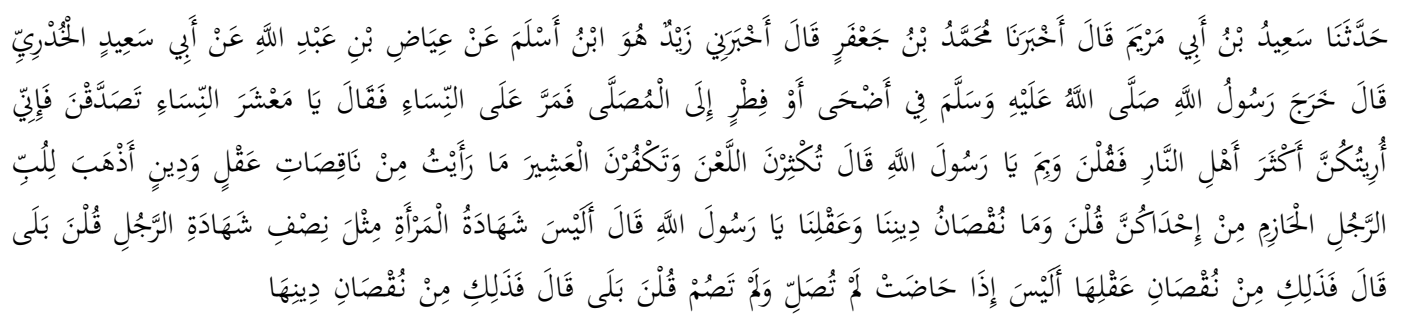

Shahih Bukhari No. 293: Telah menceritakan kepada kami Sa'id bin Abu Maryam berkata, telah mengabarkan kepada kami Muhammad bin Ja'far berkata, telah mengabarkan kepadaku Zaid- yaitu Ibnu Aslam- dari 'Iyadl bin Abdullah dari Abu Sa'id Al-Khudri ia berkata. "Rasulullah shallahu'alaihi wasallam pada hari raya 'Idul Adlha atau Fitri keluar 
menuju tempat shalat, beliau melewati para wanita seraya bersabda: "Wahai para wanita! Hendaklah kalian bersedekahlah, sebab diperlihatkan kepadaku bahwa kalian adalah yang paling banyak menghuni neraka." Kami bertanya, "Apa sebabnya wahai Rasulullah?" beliau menjawab: "Kalian banyak melaknat dan banyak mengingkari pemberian suami. Dan aku tidak pernah melihat dari tulang laki-laki yang akalnya lebih cepat hilang dan lemah agamanya selain kalian." Kami bertanya lagi, "Wahai Rasulullah, apa tanda dari kurangnya akal dan lemahnya agama?" Beliau menjawab: "Bukankah persaksian seorang wanita setengah dari persaksian laki-laki?" Kami jawab, "Benar." Beliau berkata lagi: "Itulah kekurangan akalnya. Dan bukankah seorang wanita bila dia sedang haid dia tidak shalat dan puasa?" Kami jawab, "Benar." Beliau berkata: “Itulah kekurangan agamanya" (Bukhari, 1993).

\section{b) Kualitas Hadis Kesaksian Wanita}

Pada bagian ini akan ditampilkan tabel biografi rawi.

Tabel 1. Biografi Rawi

\begin{tabular}{|c|c|c|c|c|}
\hline Nama Perawi & Wafat & Guru & Murid & $\begin{array}{l}\text { Komentar } \\
\text { Ulama }\end{array}$ \\
\hline $\begin{array}{l}\text { Abu Said } \\
\text { Al-Khudri }\end{array}$ & $59 \mathrm{H}$. & $\begin{array}{l}\text {-Nabi Saw } \\
\text {-Malik bin Sinan } \\
\text {-Abu Bakar } \\
\text {-Zaid bin Tsabit } \\
\text { - Umar bin Khatab } \\
\text { - dan lain-lain. }\end{array}$ & $\begin{array}{l}\text {-Iyadh bin } \\
\text { Abdullah } \\
\text {-Iyadh bin Hilal } \\
\text {-Ismail bin Idris } \\
\text { - Said bin Jubair } \\
\text { - dan lain-lain. }\end{array}$ & $\begin{array}{l}\text { Ibnu Hajar } \\
\text { al-'Asqalani } \\
\text { (Sahabat) }\end{array}$ \\
\hline $\begin{array}{l}\text { ‘Iyadh bin } \\
\text { ‘Abdullah }\end{array}$ & $100 \mathrm{H}$. & $\begin{array}{l}\text {-Abu Sa'id } \\
\text {-Ibn 'Amru } \\
\text {-Abu Hurairah } \\
\text {-Jabir }\end{array}$ & $\begin{array}{l}\text {-Zaid bin Aslam } \\
\text {-Ismail bin } \\
\text { Umaiyah } \\
\text {-Bukair bin 'Asyja } \\
\text { - dan lain-lain. }\end{array}$ & $\begin{array}{l}\text { Ibnu Hajar } \\
\text { al-'Asqalani } \\
\text { (Sahabat) }\end{array}$ \\
\hline $\begin{array}{l}\text { Zaid bin } \\
\text { Aslam }\end{array}$ & $136 \mathrm{H}$. & $\begin{array}{l}\text {-Iyadh bin } \\
\text { Abdullah } \\
\text {-Ibn Umar } \\
\text {-Abu Hurairah } \\
\text { - dan lain-lain. }\end{array}$ & $\begin{array}{l}\text {-Muhammad bin } \\
\text { Ja'far } \\
\text { - Hisyam bin } \\
\text { Sa'ad } \\
\text { - Dawud bin Qais } \\
\text { - dan lain-lain. }\end{array}$ & $\begin{array}{l}\text { Abu Hatim } \\
\text { ar-Rozy } \\
\text { (Tsiqah) }\end{array}$ \\
\hline $\begin{array}{l}\text { Muhammad } \\
\text { bin Ja'far }\end{array}$ & - & $\begin{array}{l}\text {-Zaid bin ‘Aslam } \\
\text {-Hamid 'Thawil } \\
\text {-Yahya bin Sa'id } \\
\text { - dan lain-lain. }\end{array}$ & $\begin{array}{l}\text {-Sa'id bin Abi } \\
\text { Maryam } \\
\text {-Abdullah bin } \\
\text { Nafi' } \\
\text {-Ziyad bin Yunus } \\
\text { - dan lain-lain. }\end{array}$ & $\begin{array}{l}\text { Ibnu Hajar } \\
\text { al- 'Asqalani } \\
\text { (Tsiqah) }\end{array}$ \\
\hline $\begin{array}{l}\text { Sa'id bin Abi } \\
\text { Maryam }\end{array}$ & $224 \mathrm{H}$. & $\begin{array}{l}\text {-Muhammad } \\
\text { bin Ja'far } \\
\text {-Sulaiman bin Bilal } \\
\text {-Al-Laits }\end{array}$ & $\begin{array}{l}\text {-Imam Bukhari } \\
\text {-Hasan bin 'Ali } \\
\text {-Abu Bakar 'Ishaq }\end{array}$ & $\begin{array}{l}\text { Ibnu Hibban } \\
\text { (Tsiqah) }\end{array}$ \\
\hline
\end{tabular}




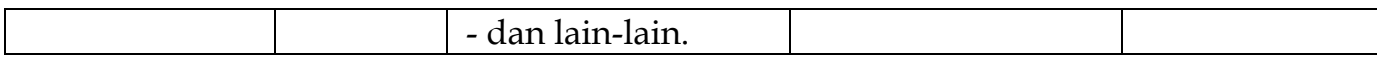

Tabel 1. Hadis ini bersambung kepada Nabi Saw. Sighat al-Tahammul wa al-Ada yang digunakan mengindikasikan adanya hubungan guru dan murid (ittishal al-sanad). Tercatat sebagai guru dan murid, antara guru dan murid bertemu dilihat dari tahun wafatnya. Para ulama menilai bahwa perawi-perawi tersebut merupakan perawi yang tsiqah (adil dan dhabit). Dan tidak ditemukannya ada kejanggalan maupun cacat. Hadis tentang kesaksian wanita dari jalur Imam Bukhari ini berstatus shahih dan dapat dijadikan hujjah (Fauziyyah, 2018).

\section{c) Syarah Hadis Kesaksian Wanita}

Para ulama telah memberikan penjelasan makna syarah dan hadis tersebut secara lugas. Ibnu Hajar al-Asqalani dalam kitabnya Fathul Bar'i menjelaskan bahwa hadis tersebut merupakan anjuran Nabi Saw terhadap kaum wanita untuk memperbanyak sedekah. Sebelumnya, Nabi Saw sudah menjanjikan kepada kaum wanita akan memberikan nasihat secara khusus kepada mereka. Selama perjalanan Isra' Mi'raj telah diperlihatkan kepada Nabi Saw bahwa sebagian besar penghuni neraka didominasi oleh kaum wanita. Hal ini sebagian disebabkan karena ditemukan dalam diri wanita banyak melaknat, ingkar terhadap kebaikan suami, dan meskipun wanita disifati dengan kurang akal dan agama, tetapi dia berpotensi dapat merusak hati atau memperdayakan akal laki-laki. Mereka tidak menyadari kekurangan yang terdapat dalam diri mereka, lalu menanyakan perihal kekurangannya di bidang akal dan agama. Nabi Saw menjawabnya dengan lembut tanpa ada unsur celaan maupun kekerasan, yaitu bahwa kurangnya akal terkait dengan perihal kesaksian wanita setengah dari kesaksian lakilaki, dan apabila sedang haid wanita tidak melakukan shalat dan puasa (alAsqalani, 2010).

Terdapat sejumlah faidah dalam hadis ini di antaranya yaitu anjuran untuk bersedekah, menghadiri shalat 'Ied bagi kaum wanita, larangan mengingkari nikmat, menjauhi perkataan-perkataan buruk seperti laknat dan celaan, sedekah dapat menolak azab dan bisa menghapus dosa sesama makhluk. Disebutkan kekurangan yang terdapat dalam diri wanita bukan bermaksud untuk mencela mereka, sebab kekurangannya itu sudah menjadi sifat dasar penciptaan, disebutkannya sifat itu adalah untuk memberikan peringatan agar seseorang tidak terfitnah oleh mereka. Oleh karena itu, azab siksaan ditimpakan karena kekufuran, bukan karena kekurangannya (al-Asqalani, 2010).

Hadis tesebut mencerminkan betapa Islam sangat memberikan perhatiannya terhadap kaum wanita. Nabi Saw memberi solusi atas kelemahan wanita yang bisa mengakibatkannya menjadi penghuni neraka. Seperti yang sudah dijelaskan sebelumnya bahwa solusi tersebut yaitu 
dengan memperbanyak sedekah, diriwayat yang lain dijelaskan bentuk dari sedekah itu bisa dengan memperbanyak amalan shaleh dan mengucapkan istigfar. Maka dengan itu, kelemahan yang didapati dalam diri wanita dapat diatasi dan ditutupi (Setiawan, 2019).

Di dalam hadis tersebut, disinggung perihal kekurangan wanita di bidang akal yaitu kesaksian wanita dinilai setengah dari kesaksian laki-laki. Hadis ini selaras dengan surat al-Baqarah ayat 282 tentang hutang piutang dan kesaksian: "dan persaksikanlah dengan dua orang saksi dari orang laki-laki (di antaramu). Jika tidak ada dua orang lelaki, maka (boleh) seorang lelaki dan dua orang perempuan dari saksi-saksi yang kamu ridhai, supaya jika seorang lupa maka yang seorang lainnya mengingatkannya" (al-Asqalani, 2010).

Musthafa Abdul Wahid berpendapat mengenai ayat tersebut, menurutnya agama Islam merupakan agama yang mengangkat derajat tinggi seorang wanita, karena kaum wanita memiliki perangai yang lembut dan penuh dengan kasih sayang, hal ini berpotensi dapat memalingkan kesaksiannya. Oleh karena itu, jika seseorang dari mereka lupa maka yang satunya dapat mengingatkannya. Hal ini dilakukan agar menghindari kesalahan dan dapat menyampaikan kebenaran. Sikap yang disebutkan di atas merupakan fitrah atau sifat alamiah yang dimiliki wanita, bukan merupakan sebuah keburukan atau kejelekan bagi mereka. Bahkan dikatakan bahwa sifat tersebut merupakan salah satu kelebihan yang tidak dimiliki oleh kaum laki-laki (Setiawan, 2019).

\section{Pemahaman Hadis menurut Nasaruddin dan Shalahuddin}

Bagian ini memaparkan hadis tentang kesaksian Wanita dalam pemahaman Nasaruddin Umar dan Henri Shalahuddin.

\section{a) Pemahaman Nasaruddin Umar}

Biografi Nasaruddin Umar akan dipaparkan sebelum ditampilkan pemahaman atau pemikiran terkait hadis kesaksian wanita.

\section{1) Biografi Nasaruddin Umar}

Prof. KH. Nasaruddin Umar, M.A, lahir 23 Juni 1959 di Ujung Bone Sulawesi Selatan. Beliau menempuh pendidikan S1 di IAIN Alaudin Ujungpandang, menyelesaikan pendidikan S2 dan S3 di IAIN Syarif Hidayatullah Jakarta. Pada jenjang magister Nasaruddin mendapatkan predikat 'sangat baik' sehingga ia bisa menyelesaikan pendidikannya tanpa harus menyertakan tesis. Dan pada tahun 1999 berhasil meraih penghargaan Doktor Terbaik di program Pascasarjana IAIN Syarif Hidayatullah dalam bidang Studi Islam (Maulana, 2017).

Nasaruddin merupakan sosok cendekiawan muslim sekaligus mufassir dari Indonesia yang terkenal melalui berbagai macam karya ilmiah, jabatan maupun pemikirannya tentang gender. Nasaruddin juga merupakan seorang Imam Besar Masjid Istiqlal Jakarta. Perjalanan 
intelektual yang dilalui Nasaruddin cukup panjang, dalam menyelesaikan riset disertasinya pun membutuhkan waktu yang lama. Hal ini dikarenakan kebutuhannya dalam penelitian, yaitu dengan mengikuti program Visiting Student di perguruan tinggi Barat yaitu McGill University Kanada, Leiden University dan Paris University dan ia juga melakukan sejumlah penelitian kepustakaan di berbagai macam negara (Maulana, 2017).

Untuk mengetahui alur pemikiran Nasaruddin, pembacaan terhadap dinamika sosial budaya partiarki khusunya di Indonesia merupakan sesuatu yang tidak bisa dipisahkan dari ide atau gagasannya. Sejarah mengungkap bahwa sebelum Islam datang, tepatnya pada zaman Jahiliah, di dalam budayanya menganggap bahwa seorang wanita memiliki kedudukan yang sangat rendah. Budaya tersebut kini dikenal dengan nama "budaya partiarki" budaya yang mentoletir adanya penindasan dan perlakukan tidak adil. Budaya partiarki telah menciptakan ketidakadilan dalam relasi gender, yang menempatkan posisi wanita selalu lebih rendah dibanding laki-laki sedangkan lelaki memiliki posisi yang lebih unggul dibanding dengan wanita. Budaya ini telah mengakibatkan kaum wanita semakin terpojok, ruang geraknya terbatasi bahkan tidak sedikit kasus kekerasan yang menimpa pada kaum wanita. Lalu Islam datang dengan ajarannya, membela kaum yang tertindas dan mengangkat derajat kaum wanita setara dengan kaum laki-laki. Hal ini tidak lain karena usaha dan perjuangan Nabi Saw dalam menepis budaya-budaya Jahiliah (Mulia, 2014).

Budaya Jahiliah dapat menyebabkan kemunduran umat manusia di berbagai belahan dunia, khususnya di Indonesia. Indonesia merupakan salah satu negara yang masyarakatnya masih melestarikan budaya partiarki, hal ini dibuktikan dengan masih tingginya kasus kekerasan seperti kasus kekerasan dalam rumah tangga (KDRT), pelecehan seksual, angka pernikahan dini dan stigma perceraian (A, 2017). Oleh karena itu, meluas interpretasi terhadap ajaran Islam yang bias gender (isu kesetaraan wanita dan laki-laki). Relasi gender adalah hasil dari kontruksi budaya, maka untuk mengubah relasi gender yang timpang dan tidak adil terhadap kaum wanita dibutuhkan upaya rekontruksi budaya. Rekontruksi budaya dibutuhkan untuk mengubah budaya partiarki menjadi budaya egalitarian (Mulia, 2014). Dalam merekontruksi budaya, pendekatan dalam isu gender banyak menggunakan teori feminis, karena faham ini lebih prihatin akan nasib kaum wanita dan beranggapan bahwa sebenarnya kodrat perempuan tidak ditentukan faktor biologis tetapi faktor budaya masyarakat (nurture). Munculnya penafsiran bias gender yang dibawa feminisme disebabkan belum jelasnya perbedaan sex dan gender dalam mendefinisikan peran laki-laki dan wanita, keterpengaruhan kisah-kisah Israiliyat, metode penafsiran banyak mengacu pada tekstual, pembaca tidak netral dalam 
menilai teks Al-Qur'an dan Hadis Nabi atau dipengaruhi pra-konsepsi yang sebelumnya sudah ada di benak penafsir (Umar, 2001).

Basis kontruksi pemikiran Nasaruddin, tidak lepas dari kondisi sosial negara Indonesia yang masyarakatnya masih melestarikan praktik-praktik partiarki, sebagaian besar karya-karya yang dihasilkannya dipicu oleh kegelisahannya sebagai cendekiawan muslim tentang masalah-masalah yang muncul pada umat Islam, seperti pemahaman masyarakat yang tumpang tindih antara konsep sex dan gender serta pemahaman dan interpretasi agama yang terkesan bias gender. Geneologi intelektual Nasaruddin banyak dipengaruhi oleh pemikiran-pemikiran Barat, ia banyak mengambil teori-teori dari Barat (seperti feminis) sehingga dalam penafsirannya terkesan lebih terbuka dan bernuansa baru (Janah, 2017).

\section{2) Pemikiran Nasaruddin Umar tentang Hadis Kesaksian Wanita}

Nasaruddin mengungkapkan pendapatnya terhadap hadis kesaksian wanita, sumber hadis yang dipakai yaitu hadis riwayat Imam Bukhari. Menurut Nasaruddin, makna dari kekurangan "akal" dan "agama" yang tersirat dalam teks hadis tersebut bukan berarti bahwa kaum wanita secara potensial tidak bisa melampaui atau mengungguli kreatifitas akal dan ibadah laki-laki. Hadis tersebut merupakan gambaran kondisi sosial kaum wanita dan laki-laki pada masa Nabi Saw. Laki-laki memiliki otoritas tinggi dalam persaksian, dikarenakan fungsi dan peran publik dipegang oleh kaum laki-laki. Kekurangan "agama" yang disifati pada diri wanita dikarenakan hanya wanita mengalami siklus menstruasi. Sedangkan lakilaki tidak menjalani siklus menstruasi, oleh karena itu laki-laki tidak diperkenankan untuk meningalkan ibadah-ibadah wajib tanpa alasan yang dibenarkan agama. Peniadaan ibadah dalam masa haid merupakan dispensasi dari Tuhan (Umar, 2001).

Kekurangan "akal" perlu ditelusuri lebih lanjut dengan makna 'aql' pada masa Nabi Saw. Apabila kekurangan akal dikaitkan dengan kualitas kesaksian, sementara kesaksian berkaitan erat dengan budaya, maka dapat ditafsirkan bahwa maksud kekurangan "akal" dalam hadis ini adalah keterbatasan penggunaan akal bagi wanita karena ada pembatasanpembatasan budaya di dalam masyarakat. Jadi sifatnya bukan permanen atau alamiah. Begitu juga dengan makna kekurangan "agama" yang dikaitkan dengan siklus haid yang membuat wanita tidak bisa melakukan ibadah, diperlukan keterangan lebih lanjut lagi. Hal ini dikarenakan bahwa haid itu bukanlah sesuatu yang dikehendaki kaum wanita, tetapi sesuatu yang bersifat alamiah terjadi pada diri wanita (Umar, 2001).

\section{b. Pemahaman Henri Shalahuddin}


Biografi Henri Shalahuddin akan dipaparkan sebelum ditampilkan pemahaman terkait hadis kesaksian wanita.

\section{1) Biografi Henri Shalahuddin}

Dr. Henri Shalahuddin MIRKH, lahir pada 5 September 1975 di Bojonegoro Jawa Tengah. Beliau menempuh pendidikan S1 di Institut Islam Darussalam (ISID) Gontor, melanjutkan pendidikan S2 di International Islamic Universiti Malaysia (IIUM) dengan meraih gelar Master of Islamic Revealed Knowlede and Heritage (MIRKH) dan menyelesaikan pendidikan doktoralnya di Universiti Malaya Kuala Lumpur Malaysia dengan menyandang gelar Doktor di bidang Gender (Mumtazi, 2020).

Henri merupakan salah satu peneliti senior di Institute for the Study of Islamic Thought and Civilizations (INSISTS), sebuah lembaga non-profit yang berkiprah dalam bidang kajian pemikiran dan peradaban Islam secara profesional dan akademis. Lembaga yang terletak di Jalan Kalibata Utara No. 84 Jakarta ini menolak tegas paham westernisasi seperti faham feminisme yang menuntut kesetaraan antara laki-laki dan perempuan. Dalam penolakannya tersebut dipengaruhi oleh pemikiran Syed Muhammad Naquib al-Attas dalam gagasan yang dicetuskannya yaitu Islamisasi Ilmu Pengetahuan (Mumtazi, 2020). Al-Attas dikenal sebagai seorang cendekiawan dan filsuf muslim yang mengkritik liberalisme Islam melalui program Islamisasi pemikiran yang berasal dari Barat. Al-Attas merupakan guru utama para pendiri INSIST selama mereka masih belajar di Malaysia. Selain Al-Attas, INSIST juga dipengaruhi oleh Wan Mohd Nur Wan Daud yang merupakan murid al-Attas (Syukur, 2019). INSISTS menerapkan cara Islamisasi yang dibawa oleh al-Attas, yaitu menghilangkan konsep-konsep Barat yang sekuler dalam Studi Islam dan memasukkan konsep-konsep Islam dalam ilmu tersebut (Firdaus, 2013).

Untuk mengetahui alur pemikiran Henri Shalahuddin, pembacaan terhadap dinamika sosial pasca runtuhnya orde baru merupakan suatu yang tidak bisa dipisahkan dengan ide atau gagasannya. Turunnya Presdien Soeharto pada tahun 1998 menandakan berakhirnya rezim Orde Baru dan terbentuknya masa reformasi. Masa reformasi ini terkenal dengan kebebasan dan keterbukaan dalam berbagai politik, sosial dan keagamaan (Lubis, 2019). Terjadi kembali pertarungan ideologis dan intelektual di antara kaum umat Islam, yakni kelompok dakwah dan kelompok pembaharuan. Kelompok pembaharuan muncul dengan nama baru yaitu "Islam Liberal" lalu mendirikan sebuah lembaga Jaringan Islam Liberal (JIL) dikordinator oleh Ulil Abshar Abdalla (Bachtiar, 2016). Tujuan didirikannya JIL ini untuk menyebarkan doktrin mengenai Islam Liberal kepada masyarakat (Daud, 2020). Selain itu pasca reformasi 1998, faham feminisme dan kesetaraan gender persfektif Barat berkembang semakin pesat dan tidak terbendung (Shalahuddin, 2016). Munculnya gerakan 
faham ini tidak lepas dari kebangkitan pembaharuan Islam dan perkembangan wacana liberalisme yang menyebar kepada masyarakat (Daud, 2020).

Basis kontruksi pemikiran Henri sebagai kalangan tradisional, tidak bisa dilepaskan begitu saja dengan kondisi sosio-politik pasca runtuhnya Orde Baru. Dilihat dari kacamata dinamika sosial, karya yang memuat ide atau gagasan Henri, merupakan konsekuansi logis dari realitas zaman yang dihadapinya. Dengan kata lain ide atau gagasan Henri tersebut merupakan respon kritisnya terhadap kelompok, sekte atau aliran yang dianggap heteredoks (menyimpang) dari orisinalitas ajaran Islam (Shalahuddin, 2016).

Karyanya secara eksplisit dan tegas mengkritisi pemikiran feminisme secara umum juga mengkritisi Pusat Studi Wanita (PSW) UIN Kalijaga secara khusus. Hal ini sebagaimana tertera dalam berbagai tulisannya baik dalam bentuk buku, jurnal maupun disertasi, yang mengarah terhadap lembaga tersebut (Shalahuddin, 2016). Apa yang dilakukan Henri tak lebih dari membenarkan teori Woodward bahwa ide atau gagasan seseorang yang dituangkan dalam bentuk karya bisa menjadi media kritis dan refleksi sosial pengarangnya (Woodward, 1993). Karyanya pun bisa dijadikan semacam membangun tradisi polemik-apologetik yaitu upaya pembelaan diri terhadap ideologi yang dipegangnya sambil menyerang ideologi pihak lain (Arif, 2018).

Di satu sisi, genealogi intelektual yang bisa ditarik sampai Syed Muhammad al-Attas dan ketersinggungannya dengan kelompok yang banyak menggugat, mengkritisi berbagai wacana westernisasi pemikiran semisal INSIST banyak mempengaruhi ide atau gagasannya. Terlebih di lembaga INSIST, Henri diberikan tempat dan jabatan yang strategis dan dikenal sebagai "Pendekar Pemikiran Islam" yang concern membahas isuisu gender (Mumtazi, 2020).

\section{2) Pemikiran Henri Shalahuddin tentang Hadis Kesaksian Wanita}

Henri mengungkapkan pendapatnya terhadap hadis kesaksian wanita, dalam kajiannya memakai sumber hadis dari Shahih Bukhari. Menurut Henri hadis tersebut tidak bermakna misoginis seperti yang sudah dipahami kaum feminis. Dalam penafsirannya Henri berpijak kepada keterangan-keterangan Ibnu Hajar al-Asqalani dalam kitab Fathul Bar'i Syarah Shahih Bukhari. Hadis tersebut menegaskan tentang nasihat Nabi Saw terhadap kaum wanita untuk memperbanyak sedekah, dan telah diperlihatkan kepada Nabi Saw selama perjalanan Isra' Mi'raj bahwa kaum wanita mendominasi dari penghuni neraka, hal ini disebabkan karena banyak melaknat, kurang mensyukuri kebaikan suaminya dan walaupun pada umunya wanita kurang akal dan agama tetapi dapat menghilangkan rasionalitas akal laki-laki. Perihal kekurangan akal dan agama terkait 
dengan kesaksian wanita yang dinilai 1:2 dari kesaksian laki-laki serta pada waktu haid tidak berpuasa dan shalat (Shalahuddin, 2016).

Henri dengan mengutip pendapat Muhammad Biltaji, menurutnya aturan kesaksian wanita $1: 2$ merupakan dalil yang bersifat qath'i (pasti). Lebih lanjut, ia mengatakan terdapat 'illat dari adanya syariat persaksian 1 : 2 ini yaitu sebagai bentuk rasa khawatir apabila seorang saksi wanita lupa terhadap kesaksian yang dibawanya, maka seseorang yang satunya lagi perlu mendampinginya. Terdapat potensi kelupaan yang besar dalam diri wanita, situasi ini tidak berubah meskipun bertambahnya pengetahuan, pengalaman serta kecerdasannya. Hal ini dikenal sebagai sifat atau tabiat asli wanita yang lebih memperhatikan terhadap perkara-perkara yang detail (juz'iyyat). Dan dalam kondisi tertentu wanita memiliki kecenderungan dalam perasaannya, hal ini disebabkan karena ketidakstabilan hormonnya pada waktu haid, hamil, seusai melahirkan dan menyusui sehingga berimplikasi terhadap kredibilitas kesaksiannya (Shalahuddin, 2016). Aturan kesaksian wanita 2 : 1 dalam kasus-kasus tertentu, bukan merupakan suatu bentuk penghinaan terhadap wanita. Kaum wanita tidak selalu akan bahagia jika semua aspek dalam kehidupannya disamakan dengan laki-laki. Sebaliknya, kebanyakan wanita justru akan merasa bahagia dan lebih baik apabila aspek-aspek perbedaannya dibiarkan tetap, baik dalam hal psikologi, biologi dan fisiologi (Shalahuddin, 2016).

\section{Analisis Komparatif Pemikiran Nasaruddin dan Shalahuddin}

Nasaruddin Umar dan Henri Shalahuddin memiliki kesamaan terhadap hadis kesaksian wanita, yakni kedua tokoh tersebut dalam kajiannya mengambil sumber hadis yang sama yaitu hadis riwayat Imam Bukhari, serta keduanya menerima bahwa hadis tersebut merupakan hadis yang shahih. Pemikiran-pemikirannya tersebut merupakan keterpengaruhan dari realitas sosial yang dihadapinya, namun memiliki perbedaan dari sudut pandang.

Nasaruddin Umar dalam memahami hadis kesaksian wanita memberikan penafsiran yang kontekstual, penafsirannya dikaitkan dengan keterkaitan antar zaman seperti situasi ketika hadis ini terjadi dengan keterkaitannya dengan masa sekarang. Instrumen yang dipakai dalam pemahaman hadisnya yaitu salah satu teori yang dibawa oleh feminis (nurture). Sedangkan Henri Shalahuddin menafsirkan hadis kesaksian wanita tidak jauh dari bunyi teks hadis tersebut (tekstual), dengan kata lain cenderung berfokus terhadap kesesuaian makna yang terdapat dalam hadis tersebut. Henri secara normatif dalam penafsirannya mengikuti ulama-ulama klasik, instrumen yang dipakai dalam pemahaman hadisnya yaitu dengan menyertakan syarah hadis. 
Nasaruddin Umar dalam penafsirannya banyak dipengaruhi oleh pemikiran-pemikiran Barat (seperti feminis), hal ini dikarenakan dalam penelitiannya dilakukan di perguruan tinggi Barat yaitu McGill University, Leiden University dan Paris University. Selain itu, Nasaruddin juga banyak melakukan penelitian kepustakaan di berbagai negara Barat. Sedangkan Henri Shalahuddin bernaung dalam lembaga INSISTS, sebuah lembaga kajian Islam yang terkenal dalam menangkis pemikiran-pemikiran liberal. Henri dalam pemikirannya banyak dipengaruhi oleh Syed Naquib al-Attas yaitu seorang cendekiawan muslim pelopor Islamisasi Ilmu sekaligus guru utama para peneliti INSISTS.

Nasaruddin Umar dalam menafsirkan hadis kesaksian wanita berpendapat bahwa kemampuan akal merupakan sesuatu yang universal, yang artinya bahwa laki-laki dan perempuan memiliki kapasitas yang sama tergantung pada penggunaan dan kreatifitas masing-masing individu dalam menfungsikan akalnya. Apabila formula kesaksian $1: 2$ ini dijadikan alasan kurangnya akal perempuan, maka hal ini bisa dipahami lewat konteks sejarah pada masa Nabi Saw. Secara umum, kondisi perempuan pada zaman itu sangat jauh berbeda dengan perempuan sekarang yang memiliki akses dan kesempatan yang sama dengan laki-laki dalam kehidupan sosial. Sedangkan Henri Shalahuddin berpendapat bahwa kaum wanita memiliki keterbatasan pada akal dan agama. Keterbatasan ini mempengaruhi kesaksian dua orang wanita sama dengan kesaksian seorang laki-laki. Kemampuan akal wanita tidak bisa disamakan dengan kemampuan akal laki-laki, hal ini berkaitan dengan beberapa tabiat yang melekat pada diri wanita, seperti terdapat potensi kelupaan yang besar serta wanita memiliki kecenderungan dalam emosinya. Aturan kesaksian wanita 2 : 1 dalam kasus-kasus tertentu, bukan merupakan suatu bentuk penghinaan terhadap kaum wanita, tetap di dalamnya terdapat beberapa syariat dan hikmah yang sudah digariskan oleh Allah.

\section{Kesimpulan}

Nasaruddin Umar mengikuti penafsiran feminis, serta memahami hadis kesaksian wanita secara kontekstual. Nasaruddin berpendapat bahwa akal merupakan sesuatu yang bersifat universal, laki-laki dan wanita memiliki kapasitas yang sama dalam persaksian. Sedangkan Henri Shalahuddin dalam penafsirannya secara normatif mengikuti ulama-ulama klasik dan memahami hadis kesaksian wanita cenderung tekstual. Menurutnya seorang wanita memiliki keterbatasan pada akal dan agama sehingga menyebabkan kesaksian dua wanita sama dengan satu laki-laki. Kajian ini membuktikan bahwa syarah tidak hanya menjelaskan kandungan hadis saja, akan tetapi syarah bisa dijadikan sebagai sarana legimitasi berbagai kepentingan, motif ideologis serta kritik sosial. Signifikansi kajian ini pun mempertegas bahwa pemahaman seseorang 
tidak pernah lepas dari konteks historitas yang melingkup pemikirnya. Penelitian ini diharapkan dapat bermanfaat dan menambah ilmu dan wawasan pada semua lapisan masyarakat tentang bagaimana pemahaman Islam feminis dan Islam tradisionalis tentang hadis kesaksian wanita. Dalam penelitian ini terbatas pada kajian terhadap hadis kesaksian wanita saja, sehingga penelitian selanjutnya diharapkan bisa mengembangkannya untuk mengkaji diskursus lainnya. Penelitian ini merekomendasikan untuk meneliti lebih lanjut mengenai hadis kesaksian wanita dengan pendekatan ilmu-ilmu sosial.

\section{Daftar Pustaka}

al-Asqalani, I. H. (2010). Fathul Bari Jilid 1. Jakarta: Pustaka Syafi'i.

Andriyani, L. (2017). Pembacaan Hermeneutika Hadits Tentang Perempuan Kekurangan Akal dan Agama: Persfektif Hans-Georg Gadamer. Repository UIN Syarif Hidayatullah Jakarta, 76.

Anshoruddin. (2004). Hukum Pembuktian Menurut Hukum Acara Islam dan Hukum Positif. Yogyakarta: Pustaka Pelajar.

Arif, S. (2018). Islam dan Diabolisme Intelektual. Jakarta: INSIST.

Bachtiar, T. A. (2016). Lajur-Lajur Pemikiran Islam: Kilasan Pergulatan Intelektual Islam di Indonesia. Depok: Komunitas Nuun.

Bukhari, I. (1993). Shahih Al-Bukhori. Beyrouth-Liban: Dar El Fiker.

Darmaji, A. (2013). Dasar-dasar ontologis pemahaman hermeneutik HansGeorg Gadamer. Refleksi, 13(4), 469-494.

Darmalaksana, W. (2020). Cara Menulis Proposal Penelitian. Bandung: Fakultas Ushuluddin UIN Sunan Gunung Djati Bandung.

Daud, F. K. (2020). Feminisme Islam Di Indonesia: Antara Gerakan Modernisme Pemikiran Islam Dan Gerakan Perjuangan Isu Gender. Jurnal Harkat: Media Komunikasi Gender, 16(2), 102-116.

Fauzan, S. (2005). Al-Mulakhkhasanul Fiqhi. Jakarta: Gema Insani Press.

Fauziyyah, N. Z. (2018). Penyelesaian Hadis Kontradiksi tentang Kesaksian Perempuan (Kajian Mukhtalif Al-Hadists). Repository UIN Syarif Hidayatullah, iv.

Fuadhaili, A. (2005). Wanita Dilembaran Suci. Yogyakarta: Pilar Media.

Helim, I. E. (2015). Konsep Kesaksian. Malang: Setara Press.

Henri, S. (2016). Wacana kesetaraan gender dalam pemikiran Islam di Institusi Pengajian Tinggi Islam Negeri di Indonesia: Kajian kes di Universitas Islam Negeri Sunan Kalijaga Yogyakarta/Henri Shalahudin (Doctoral dissertation, University of Malaya).

Janah, N. (2017). Telaah Buku Argumentasi Kesetaraan Gender Perspektif Al-Qur'an Karya Nasaruddin Umar. Sawwa: Jurnal Studi Gender, 12(2), 167-186.

Khariroh. (2010). Hadis-hadis tentang Kekurangan Akal dan Agama Bagi Perempuan (Studi Kritik Sanad dan Matan dalam kitab Sahih Al- 
Bukhori dan Sahih Muslim. UIN Sunan Kalijaga Yogyakarta.

Maulana, L. (2018). Pembacaan Tafsir Feminis Nasarudin Umar Sebagai Tranformasi Sosial Islam. MUWAZAH: Jurnal Kajian Gender, 9(1), 5165.

Muhtador, M. (2016). Sejarah Perkembangan Metode dan Pendekatan Syarah Hadis. Riwayah, 2(2), 259-272.

Mulia, M. (2014). Kemuliaan Perempuan dalam islam. Jakarta: Gramedia.

Mumtazi, F. Gagasan Institute for Study of Islamic Thought and Civilizations (INSISTS) tentang Kesetaraan Gender 2004-2017 (Master's thesis, Sekolah Pascasarjana UIN Syarif Hidayatullah Jakarta).

Muqtada, M. R. (2014). Kritik Nalar Hadis Misoginis. Musãwa Jurnal Studi Gender dan Islam, 13(2), 87-98.

Sakina, A. I. (2017). Menyoroti budaya patriarki di Indonesia. Share: Social Work Journal, 7(1), 71-80.

Samsudin, S. (2019). Sejarah Munculnya Pemikiran Islam Liberal di Indonesia. Patanjala, 11(3), 483-498.

Setiawan, A. (2019). Perempuan sebagai Mayoritas Penghuni Neraka dan Kelemahannya dari Sisi Akal dan Agama. TAJDID: Jurnal Ilmu Ushuluddin, 18(1), 1-22.

Suryani, E. (2012). Filologi. Bogor: Ghalia.

Umar, N. (2001). Argumen Kesetaraan Gender Persfektif Al-Qur'an. Jakarta: Paramadina.

Woodward, M. R. (1993). Textual Exegesis As Social Commentary: Religious, Social, and Political Meanings of Indonesian Translations of Arabic Hadith Texts. The Journal of Asian Studies, 52(3), 565-583.

Zubair, A. B. (2010). Metodologi Penelitian Filsafat. Yogyakarta: Kanisius. 